2020-09-04

Soil erosion assessment in a semi-arid environment: a case study from the Argana Corridor, Morocco

Bou-imajjane, L

http://hdl.handle.net/10026.1/16233

10.1007/s12665-020-09127-8

Environmental Earth Sciences

Springer (part of Springer Nature)

All content in PEARL is protected by copyright law. Author manuscripts are made available in accordance with publisher policies. Please cite only the published version using the details provided on the item record or document. In the absence of an open licence (e.g. Creative Commons), permissions for further reuse of content should be sought from the publisher or author. 


\title{
Soil erosion assessment in a semi-arid environment:acasestudy from the Argana Corridor, Morocco
}

\author{
Latifa Bou-imajjane $^{1} \cdot$ Mhamed Alaeddine Belfoul $^{1} \cdot$ Racha Elkadiri $^{2} \cdot$ Martin Stokes $^{3}$
}

Received: 22 May 2019 / Accepted: 3 August 2020

(C) Springer-Verlag GmbH Germany, part of Springer Nature 2020

\begin{abstract}
Soil erosion is a widespread problem that continues to expand in magnitude and scope due to ever-changing anthropogenic and climatic conditions. The High Atlas Mountains in Morocco are a typical case where this problem affects the ecological and socioeconomic activities of the region. The main objective of this study is to provide an erosion risk analysis of the Argana Corridor in the High Atlas of Morocco using GIS, Remote Sensing and the Revised Universal Soil Loss Equation (RUSLE). The erosion assessment is based on various controlling factors including climate, topography, vegetation cover, soil erodibility and soil conservation practices. Findings indicate that the study area is subjected to significant erosion, reaching an average annual soil loss rate of $47.52 \mathrm{t} / \mathrm{ha} /$ year, and an annual erosion amount of 5,233,840 tons. Collectively, the methodology and results provide a decision support system for stakeholders in the region, and a framework for studies in data-scarce regions.
\end{abstract}

Keywords Soil erosion · RUSLE · Remote sensing · GIS · Argana Corridor · Western High Atlas · Morocco

\section{Introduction}

Soil erosion is a form of land degradation inducing negative socioeconomic and environmental impacts (Del Mar López et al. 1998; Lal 1998), such as desertification, low agricultural yield (Merzouk et al. 1993) and siltation of

Electronic supplementary material The online version of this article (https://doi.org/10.1007/s12665-020-09127-8) contains supplementary material, which is available to authorized users.

$\triangle$ Latifa Bou-imajjane

latifa.bou-imajjane@edu.uiz.ac.ma

Mhamed Alaeddine Belfoul

m.belfoul@uiz.ac.ma

Racha Elkadiri

Racha.ElKadiri@mtsu.edu

Martin Stokes

M.Stokes@plymouth.ac.uk

1 Geology Department, Faculty of Science Agadir, Ibn Zohr University, Agadir, Morocco

2 Geosciences Department, Middle Tennessee State University, Murfreesboro, USA

3 School of Geography, Earth and Environmental Sciences, Plymouth University, Plymouth, UK dams (Elaloui et al. 2017). Such erosion remains the principal cause of soil degradation worldwide, and is of criti-cal concern for the sustainable management of agricultural resources and downstream water bodies. An understanding of the factors controlling erosional processes is vital when developing methods to mitigate the impacts associated with soil degradation. Moreover, soil erosion continues to dete-

riorate temporally and spatially (Hoyos 2005; Pandey et al. 2009) due to the combined effect of climate change and anthropogenic activities, including but not limited to deforestation, grazing, and urban expansion (Vezena and Bonn 2006; Boudhar et al. 2007).

Morocco, and especially the Western High Atlas, is considered to be one of the most vulnerable areas to soil erosion in the region. This is mainly due to the absence of vegeta- tion, the presence of steep slopes, the friable lithology and the intense rainfall events (Heusch 1971). Collectively, these factors highlight the high erosion risk in the area and demon- strate a strong requirement for soil degradation assessment and mitigation.

Technological developments, especially in the areas of Remote Sensing and GIS, have significantly improved the identification and quantification of erosion risks at relatively low cost (Wilson and Lorang 2000; Boggs et al. 2001; Wang et al. 2003; Jasrotia and Singh 2006). These approaches 
commonly use the Universal Soil Loss Equation (USLE) model of Wischmeier and Smith (1978) for water erosion of landscapes. This widely utilized model has been modi- fied by numerous researchers (Wischmeier and Smith 1978; Arnoldus 1977; Foster et al. 1981; Merzouk 1985; McCool et al.1987; Renard et al.1991; Desmet and Govers 1996; Van der Knijff et al.2000), and is now referred to as the Revised Universal Soil Loss Equation (RUSLE). In this study, the RUSLE is adjusted to the local conditions. In addition, the combined use of RUSLE, GIS and Remote Sensing allow us to mitigate the lack of detailed field datasets. Our study aims at mapping the areas subjected to high erosion risk, analysing the controlling factors and quantifying soil loss in the area. The resulting soil erosion assessment provides a decision support system for local stakeholders to better man- age natural resources and implement conservation strate- gies. Furthermore, the constructed GIS, Remote Sensing and RUSLE-based methodology could be applied to any similar environments, especially ones that lack field data.

\section{Materials and methods}

\section{Study area}

The Argana Corridor is located in the west of the Moroccan High Atlas, northeast of the city of Agadir (Fig. 1). It is bordered by the mountainous reliefs of Imi N'tanout (north) and Amsekroud (south), and is positioned between UTM Easting coordinates 461,216 and 509,293 $\mathrm{m}$ and UTMNorthing coordinates 3,377,601 to 3,445,078 $\mathrm{m}$ (Coordinate system WGS_84_UTM_ZONE_29N).

Along the western side of the study area, the dominant geological formation comprises Jurassic clastic, carbonate and evaporite sedimentary rocks (Tixeront 1973, 1974). The geology of the central area is mostly Permo-Triassic clas- tic rocks (i.e. sandstones, conglomerates, clays and sandy silts) cross-cut by basalt and dolerite igneous rocks (Tixeront 1973, 1974; Jalil 2001; Medina et al. 2001). Along the east- ern side, Permo-Triassic formations are in discordance with Palaeozoic metamorphic basement rocks.

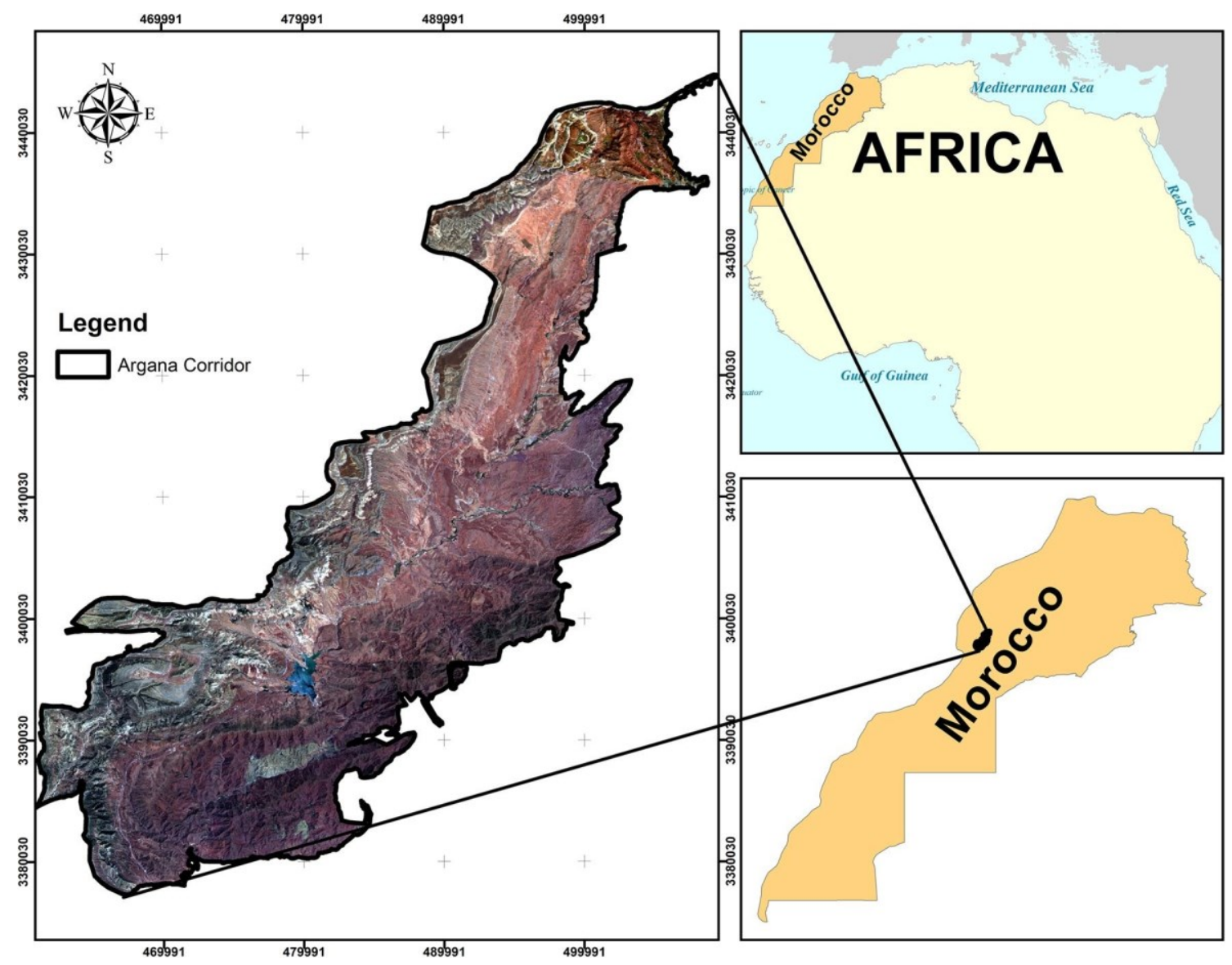

Fig. 1 Location of the Argana Corridor, Morocco 
The Argana Corridor forms a depression between the Jurassic formations to the west, and the Paleozoic mas- sif to the east. This depression results from erosion by the Assif Ait Moussa River and its tributaries (Ambroggi 1963; Brown 1980) forming the 'Argana Corridor'. The area is bounded to the south by the El Menizla fault and to the north by the Ichemraren-Imi N'Tanout fault.

The study area is characterized by an arid to a semi-arid climate with altitudes that range from 240 to $1950 \mathrm{~m}$. A

dam was built in 1981 on the Issen River, with a capacity of $214 \mathrm{~mm}^{3}$ to supply the needs of the local population

for drinking and farming purposes including arboriculture and livestock. The reservoir storage capacity is reported, by local stakeholders, to be decreasing due to soil erosion.

\section{Methodology}

This study uses cartographic erosion modeling based on the USLE model (Wischmeier and Smith 1978) with revisions and adaptions to the High Atlas conditions (Arnoldus 1977), referred to as the RUSLE. The main purpose of this approach is to predict the average annual soil loss rate for different land conservation practices in association with soil type, rainfall pattern, land uses and topography. These factors are the main controlling parameters in the erosion process (Wischmeier and Smith 1978).

Erosion is a product of rainfall erosivity (the $R$ factor, which equals the potential energy of rain); the resistance of the environment, which is represented by $K$ factor (soil erodibility), LS (the topographic factor), $C$ factor (plant

cover and agricultural techniques) and $P$ factor (soil conservation practices). Since it is a multiplier, if one factor tends towards zero, erosion will also tend towards zero

\section{(Wischmeier and Smith 1978).}

This model allows the spatial modeling of erosion, by integrating thematic maps representing various controlling factors into a geographic information system (Lu et al. 2004; Dabral et al. 2008; Pandey et al. 2009; Bonilla et al. 2010). The controlling factor maps are calculated separately using Remote Sensing-based products, and are integrated using Eq. (1) into a final thematic erosion map that predicts the amount of erosion for each pixel.

The Eq. (1) expresses soil loss as a product of five factors:

$A=R \times K \times \operatorname{LS} \times C \times P$,

where $A$ is the rate of soil loss (t/ha/year); $R$ : erosivity of rainfall (MJ $\mathrm{mm} / \mathrm{ha} \mathrm{h}$ year), $K$ is the soil erodibility ( $\mathrm{t} \mathrm{h} / \mathrm{ha}$ $\mathrm{MJ} \mathrm{mm}$ ), $L S$ is the topographic factor ( $L$ in $\mathrm{m}, S$ in\%), $C$ is the plant cover factor, and $P$ is the factor of soil conserva- tion practices.
Erosivity factor of rain $(\boldsymbol{R})$

The erosivity by rain is the potential capacity of precipitation to cause water erosion (Hudson 1981). It provides a means to predict the degree of vulnerability to erosion using the RUSLE. It is expressed as the product of rainfall kinetic energy at the maximum intensity over $30 \mathrm{~min}$ (130) of rainfall (Wischmeier and Smith 1978; Sanoussi Manzo 2011), calculated by the following formula:

$R=E \times 130$,

where $E$ is the kinetic energy of the rainfall (MJ/ha), and $/ 30$ is the maximum intensity of rainfall in 30 min expressed in $\mathrm{mm} / \mathrm{h}$.

The kinetic energy of the rainfall is given by the following formula:

$$
E=210+89 \log 10 \times I
$$

where $E$ is the kinetic energy of the rainfall (MJ/ha), and I is the intensity of rainfall.

The required datasets for Eqs. (2) and (3) are not available for Morocco, since public precipitation datasets are only available for monthly and annual time series. We used instead an alternative approach (Arnoldus 1977) that takes into account the local climate and uses monthly and annual rainfall data to calculate the $R$ factor (Table S1, ESM only). We applied the latter approach to data from 19 climatic stations (Fig. 2) in and around the Argana Corridor. The $R$ factor of each station has been calculated according to the following formula:

$$
R=\stackrel{n=12}{\rightarrow} \cdot \mathrm{MRi}^{2} / \mathrm{AR},
$$

where $R$ is the climatic aggressivity index (MJ mm/ha $\mathrm{H}$ year), MRi is the mean monthly precipitation ( $\mathrm{mm})$, and $A R$ is the average annual precipitation $(\mathrm{mm})$.

The rainfall aggressivity point data were then interpolated using the IDW interpolation method, to obtain a thematic map of rainfall erosivity for the Argana Corridor. The IDW method is a widely deterministic interpolation method successfully used and evaluated for similar environments. The interpolated precipitation value is assigned based on the proximity to the known value location. The result is a rasterized map in which each pixel has an $R$ value assigned to it.

Soil erodibility factor $(\boldsymbol{K})$

The $K$ factor is a measure of the vulnerability of soil particles to detachment and transportation by water. Thus, it represents the degree of cohesion and the resistance of the particles to erosion. This factor varies depending on climatic conditions, 


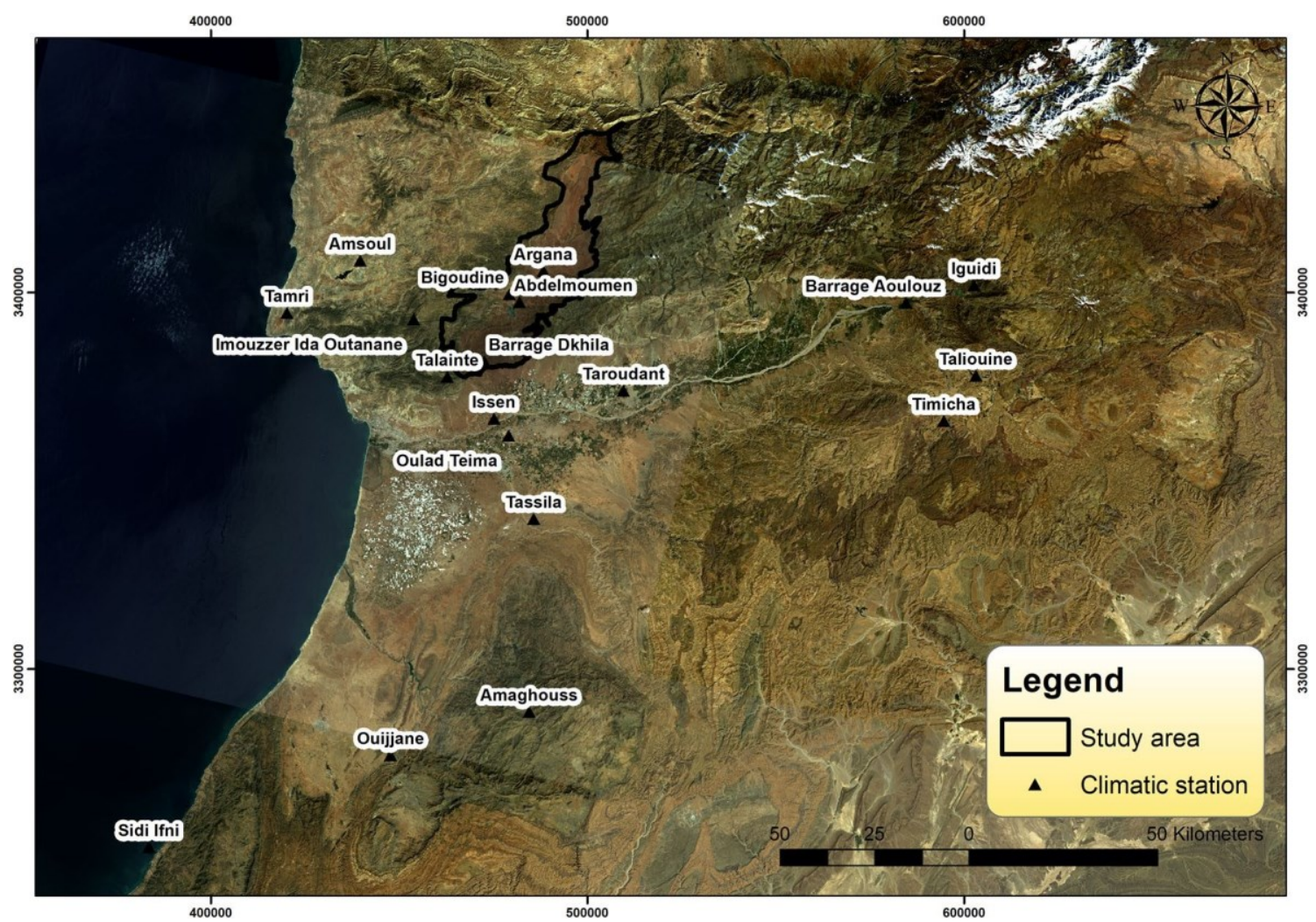

Fig. 2 Spatial distribution of climatic stations (with XY coordinates in Table S2, ESM only) interpolated using IDW method based on Erosivity factor's value

which also affect the distribution of soil particles (Safi et al. 2018). It is a function of the soil permeability, soil organic matter content, and most importantly, the soil texture and

structure. As a proxy for these datasets, we created the erod-ibility map based on the universal soil database. The soil erod-ibility factor is calculated using the formula of Sharpley and Williams (1990) accounting for the percentage of sand, silt and clay, and also the organic carbon content (Eq. 5).

$K=A \times B \times C \times D \times 0.1317$

where

$\mathrm{A}=0.2+0.3 \exp -0.0256 \mathrm{SAN} 1-\frac{\mathrm{SIL}}{100}$,

$$
\mathrm{B}=\frac{\Sigma}{\mathrm{CLA}+\mathrm{SIL}} \Sigma_{0.3}
$$

$$
\mathrm{C}=1.0-\frac{0.25 C}{C+\exp [(3.72-2.95 C)]} \text {, }
$$

$\mathrm{D}=1.0-\mathrm{SN} 1+\exp \left[\left(-\frac{0.70 \mathrm{SN} 1}{2.41+22.9 \mathrm{SN} 1)]}\right.\right.$,

where SAN, SIL and CLA represent the percentage of sand, silt and clay, respectively. $C$ is the organic carbon content; and SN1 is the subtracted sand content of 1 and divided by 100.

\section{Topographic factor $(L S)$}

The topographic factor is one of the most important factors in relation to erosion process. It considers the length and gradient of slopes that affect the production and transport of sedimentary deposits (Roose 1994). The amount of sediment

depends on the slope gradient, which does not differentiate between linear erosion and sheet erosion (Renard et al. 1997; Lu et al. 2004; Krishna Bahadur 2009). The topographic factor also assesses the influence of the slope on the rate of erosion, where the steeper the slope, the greater the runoff. The $L S$ factor was calculated using the Wischmeier and Smith (1978) formula, with developments by Bizuwerk et al. (2003) (Eq. 10). We extracted the slope gradient (\%) and its length, respectively, from a slope map and a flow map based

on a 12.5 m-DEM within a GIS environment. 
$L S=\left(L / 22.13^{m}\right) 0.065+0.045 S+0.0065 S^{2}$,

where $S$ is the gradient of the slope in \%; $L$ is the length of the slope in meters. $L=$ flow accumulation $\times$ DEM spa- tial resolution. The value of " $m$ " varies between 0.2 and 0.5 depending on slope percentage. A value of 0.2 is attributed to areas with slope $<1 \%$, values of 0.3 and 0.4 correspond, respectively, to areas with slope percentages that vary between $1-3$ and $3-5$, and a value of 0.5 is attributed to areas with slopes > 5\%, (Wischmeier and Smith 1978; Bizuwerk et al. 2003).

Vegetation cover factor $(\boldsymbol{C})$

The vegetation cover factor is a key parameter for the dynamics of the studied environment (Kalman 1967). When present, the vegetation cover minimizes the effects of rainfall, soil erodibility and topography, maximizing soil infiltration and permeability as well as fixing soils.

The $C$ factor differentiates between bare and covered land, the degree of cover, and the type of vegetation (Wischmeier and Smith 1978). The main categories of vegetation in the area are: trees (Argania spinosa), shrubs (Vachellia gum- mifera, Periploca angustifolia, Searsia tripartite, Ziziphus lotus), bushes (Atriplex halimus, Salsola oppositifolia, Sal- sola vermiculata, Haloxylon scoparium, Anabasis oropedio- rum), low bushes (Lavandula multifida, Salvia aegyptiaca, Teucrium collinum) and herbaceous plants (Asphodelus tenuifolius, Stipa retorta, Paronychia arabica, Notoceras bicorne).

In this study, the $C$ factor was generated using a Landsat $8 \mathrm{OLI}$ image with a resolution of $30 \mathrm{~m}$. The image was processed using radiometric and atmospheric corrections, followed by an application of normalized difference vegetation index (NDVI) formula (Eq. 11), and then a classification of NDVI map into five classes. The NDVI varies from -1 to 1 , where high values relate to areas of dense vegetation cover, and low values correspond to areas with low vegetation cover to bare lands. This index provides information on the density and health status of the vegetation (Jensen 2000). Results were validated using field verification. The final classification includes a five-class standardized vegetation index as shown in Table 1.

\begin{abstract}
Table $1 C$ factor classification
depending on the type of land

use (Wischmeier and Smith
\end{abstract}

1978)

\begin{tabular}{ll}
\hline Land use & -factor \\
\end{tabular}

Bare land

0.70

Cultivated land

0.60

Land with moderate vegetation cover

Dense vegetation

0.05

Water (dam)

$\mathrm{NDVI}=(\mathrm{NIR}-R) /(\mathrm{NIR}+R)$

where the NIR represents the near infrared band, and $R$ represents the red band.

Factor of soil conservation practices $(P)$

The soil conservation practice factor is related to the used agricultural approaches, such as ridging, contour ploughing, slope terracing, alternating strip crops, etc. All of these factors serve as soil conservation practices. Given the unavailability of these datasets, we used results from a study by Shin (1999) conducted in a similar environment, in which each type of practice is considered to have a direct relationship with slope values. Therefore, this factor has been estimated as a function of slope variations, varying between 0 and 1 . The steeper slopes correspond to 1 and represent the areas without any soil conservation practices (Table 2 ).

\section{Results and discussion}

\section{Rainfall erosivity factor $(R)$}

The erosivity factor of rain describes the aggressivity of rain to produce soil loss, due to the intensity of the energy under effect of precipitated (splash) and run-off water (Boiffin 1994). The surface waters (runoff) flow with a significant speed participating in the detachment process of soil par-ticles. Furthermore, the hydro-chemical properties of these waters can experience many changes depending on geo- logical and hydrological conditions of soils (Al-Arifi et al. 2013), which may increase the erosion in the targeted region. The erosivity factor was calculated on the basis of monthly and annual climatic data for 19 weather stations, located in and around the study area. The used approach of Arnoldus (1977) is the most recent and it has been proven that it is appropriate for the Moroccan conditions (Issa et al. 2016; Elaloui et al. 2017).

The rainfall erosivity map shown in Fig. 3 is a spatial representation of the $R$ factor variations throughout the Argana Corridor. Erosivity values in this area ranged between 24.47 and $53.89 \mathrm{MJ} \mathrm{mm} /$ ha $H$ year with an average of 35.98 and a standard deviation of 5.90. These results show that the

Table 2 Factor of soil

conservation practices as a

function of slope (Shin 1999)
Slope (\%)

$P$-factor

\begin{tabular}{ll}
\hline $0.00-7.00$ & 0.55 \\
$7.01-11.30$ & 0.60 \\
$11.31-17.60$ & 0.80
\end{tabular}

17.61-26.80

0.90

$>26.81$

1.00 
Fig. 3 The spatial distribution of rainfall erosivity factor $(R)$ in the Argana Corridor

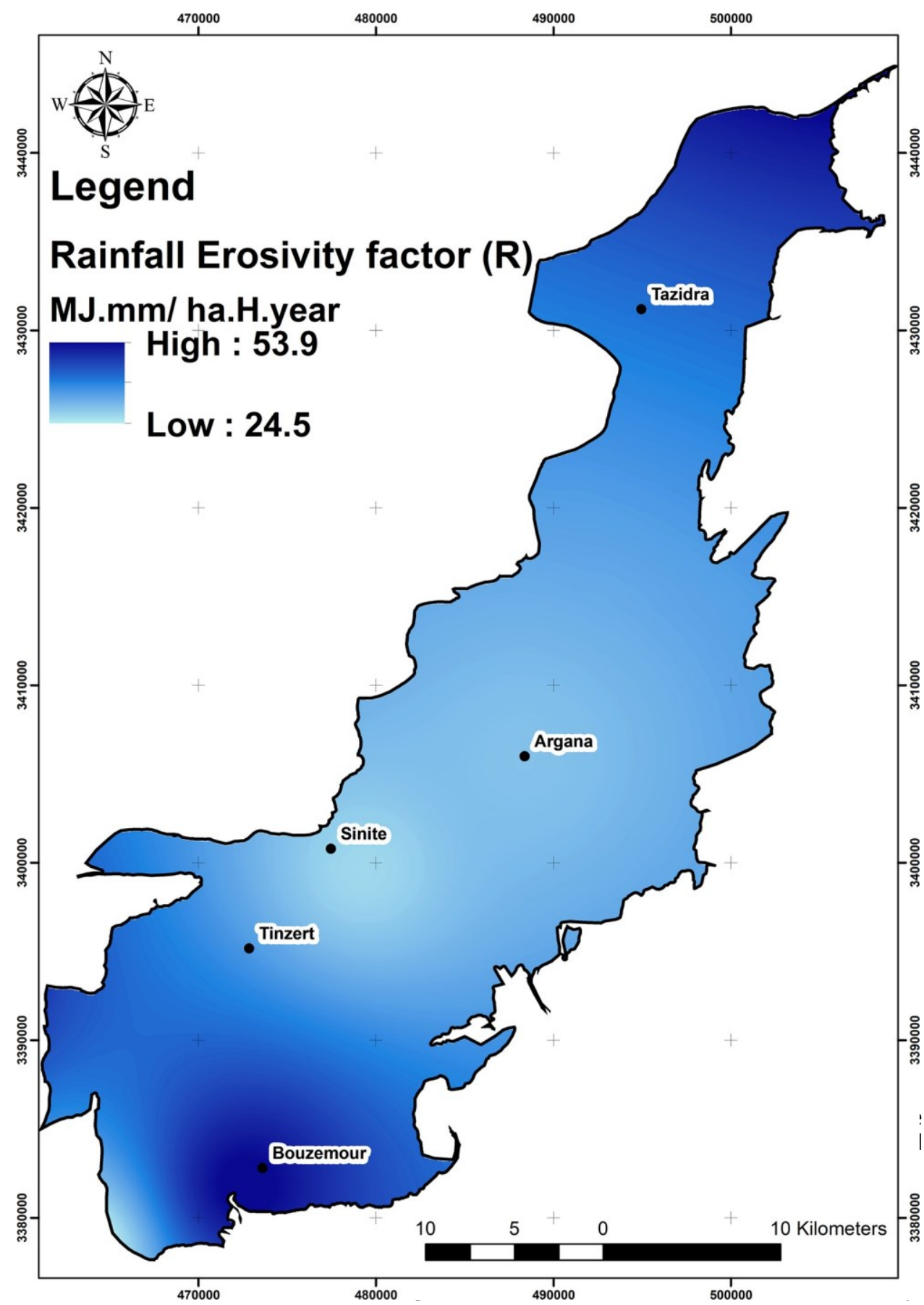

depends on the soil type, climatic variability and types of applied agriculture. Table 3 shows the distribution percentages of the $K$ factor values throughout the Argana Corridor
Argana Corridor, in spite of its semi-arid context, is subject to significant climatic aggressiveness.

To better show the influence of this factor, we have opted for the standard deviation classification as presented in Table 3 to classify the $R$ factor map into five significant classes. The highest values of erosivity were indicated by $R$ factor of more than $38 \mathrm{MJ} \mathrm{mm} /$ ha $\mathrm{H}$ year, occurring in both the northern and southern areas of the Argana Corri- dor. This implies that $31.57 \%$ of the surface area is at risk to erosion by rainfall and about $26 \%$ of the area is subjected to 
Table 3 Classification of the erosivity factor $(R)(\mathrm{MJ} \mathrm{mm} / \mathrm{ha} \mathrm{H}$ year), erodibility factor $(K)$ (t ha $\mathrm{H} / \mathrm{ha} \mathrm{MJ} \mathrm{mm}$ ) and topographic factor (LS) by surface area in the Argana Corridor

\begin{tabular}{|c|c|c|c|c|c|c|c|c|c|}
\hline \multirow[t]{2}{*}{ Classes } & \multicolumn{3}{|c|}{ Erosivity factor $(R) \mathrm{MJ} \mathrm{mm} /$ ha $\mathrm{H}$ year } & \multicolumn{3}{|c|}{$\begin{array}{l}\text { Erodibility factor }(K) \text { t ha } \mathrm{H} / \mathrm{ha} \mathrm{MJ} \\
\mathrm{mm}\end{array}$} & \multicolumn{3}{|c|}{ Topographic factor (LS) } \\
\hline & Value & Area (ha) & Area (\%) & Value & Area (ha) & Area (\%) & Value & Area (ha) & Area (\%) \\
\hline Very high & $44.84-53.89$ & $11,375.40$ & 10.32 & - & - & - & $16.69-568.02$ & 2776.00 & 2.52 \\
\hline High & $38.93-44.84$ & $23,405.52$ & 21.25 & 0.0227 & 375.86 & 0.34 & $10.68-16.69$ & 2486.55 & 2.26 \\
\hline Moderate & $33.02-38.93$ & $28,575.89$ & 25.94 & 0.0183 & $28,694.19$ & 26.05 & $4.67-10.68$ & 4761.30 & 4.32 \\
\hline Low & $27.12-33.02$ & $46,152.98$ & 41.90 & 0.0138 & $81,072.94$ & 73.61 & $0.00-4.67$ & $100,119.13$ & 90.90 \\
\hline Very low & $24.47-27.12$ & 633.21 & 0.57 & - & - & - & - & - & - \\
\hline Total & & 110,143 & 100 & & 110,143 & 100 & & 110,143 & 100 \\
\hline
\end{tabular}

by surface area. The $K$ factor ranges from 0.0138 to 0.0227 $\mathrm{t}$ ha $\mathrm{H} / \mathrm{ha} \mathrm{MJ} \mathrm{mm}$, with the 0.0138 class occupying more than $70 \%$ of the area implying a dominance of soils with low erodibility, and $26 \%$ of soils with medium erodibility and only 0.34 of the area with highly erodible soils. According to the erodibility map (Fig. 4), moderate to high $K$ values are located in the northern and eastern parts of the Corridor.

\section{Topographic factor (LS)}

The topographic factor is considered to be one of the essential components that conditions the erosion process from the perspective of slope gradient and slope length. In the study area, topography correlates with the soil type and lithol- ogy (Roose et al. 1993), where in most cases, steep slopes are protected by competent soils. This implies that erosion occurs in places where the topography is moderate.

The topographic factor varies from 0 to 568.02 , with the resulting map (Fig. 5) illustrating a categorization of the dominant slopes. Table 3 shows a classification of the $L S$ factor using the standard deviation approach. The class of low values represents the weak slopes and characterizes more than $90 \%$ of the total surface, whilst the steepest slopes only represent $2.52 \%$ of the total surface area.

\section{Vegetation cover factor $(C)$}

$C$ factor refers to the degree of vegetation coverage in a given location. The studied area is characterised by the existence of floral diversity, and this provides important microbiological activity which in turn increases soil fertil- ity (Heinze et al. 2014).

The vegetation in the Argana Corridor varies from areas of dense to low vegetation cover. This vegetation density varies depending on seasons and climatic conditions. Agricultural lands are affected by cropping frequency and irrigation type, with the latter can play a crucial role in microbiological contribution and organic matter content, collectively contributing to soil fertility and, thus, vegetation growth (ElNahhal et al. 2013; Heinze et al. 2014).

According to Wischmeier and Smith (1978), the $C$ fac- tor varies between 0 for water bodies and 0.70 for bare soil. Values of $0.05,0.10$, and 0.60 correspond, respectively, to dense vegetation, moderate vegetation and cultivated lands. These land uses are scattered in the north and south of the region, especially around the edges. In the vegetation cover map (Fig. 6), the higher values imply areas of greater erosion risk. The dominant category for the Argana Corridor is bare land, which covers almost $80 \%$ of the surface area (Table 4). The dominance of this type of land illustrates the sensitivity of the study area to erosion processes.

\section{Soil conservation practices factor $(P)$}

The $P$ factor values are lower than or equal to 1 . A value of 1 corresponds to land without soil conservation practices. The $P$ factor varies according to the agricultural practice or the adopted control of erosion, as well as the slope. Note that in this study, the $P$ factor values were determined according to the slope value. Low and very low values correspond to areas of low slopes. In Table 4, values vary between 0.55 and

0.6 for the zones with low to very low slope and the value of 0.8 (moderate slope) stands for moderate $P$ factor. Values between 0.9 and 1 correspond to areas with steeper slopes. It represents almost $50 \%$ of the Argana Corridor (Fig. 7).

\section{Final erosionmap}

The potential erosion map is the product of the combination of factors from the RUSLE model. This involves combining the controlling factors (i.e. climatic aggressivity factor $R$, erodibility of soils $K$, topographic factor $L S$, land cover $C$ and $P$ erosion control practices) within the GIS environment. These factors vary as follows:

- Map of climatic aggressivity $(R)$ : from 24.47 to $53.89 \mathrm{MJ} \mathrm{mm} / \mathrm{ha} \mathrm{H}$ year. 
Fig. 4 The spatial distribution of the soil erodibility factor $(K)$ in the Argana Corridor

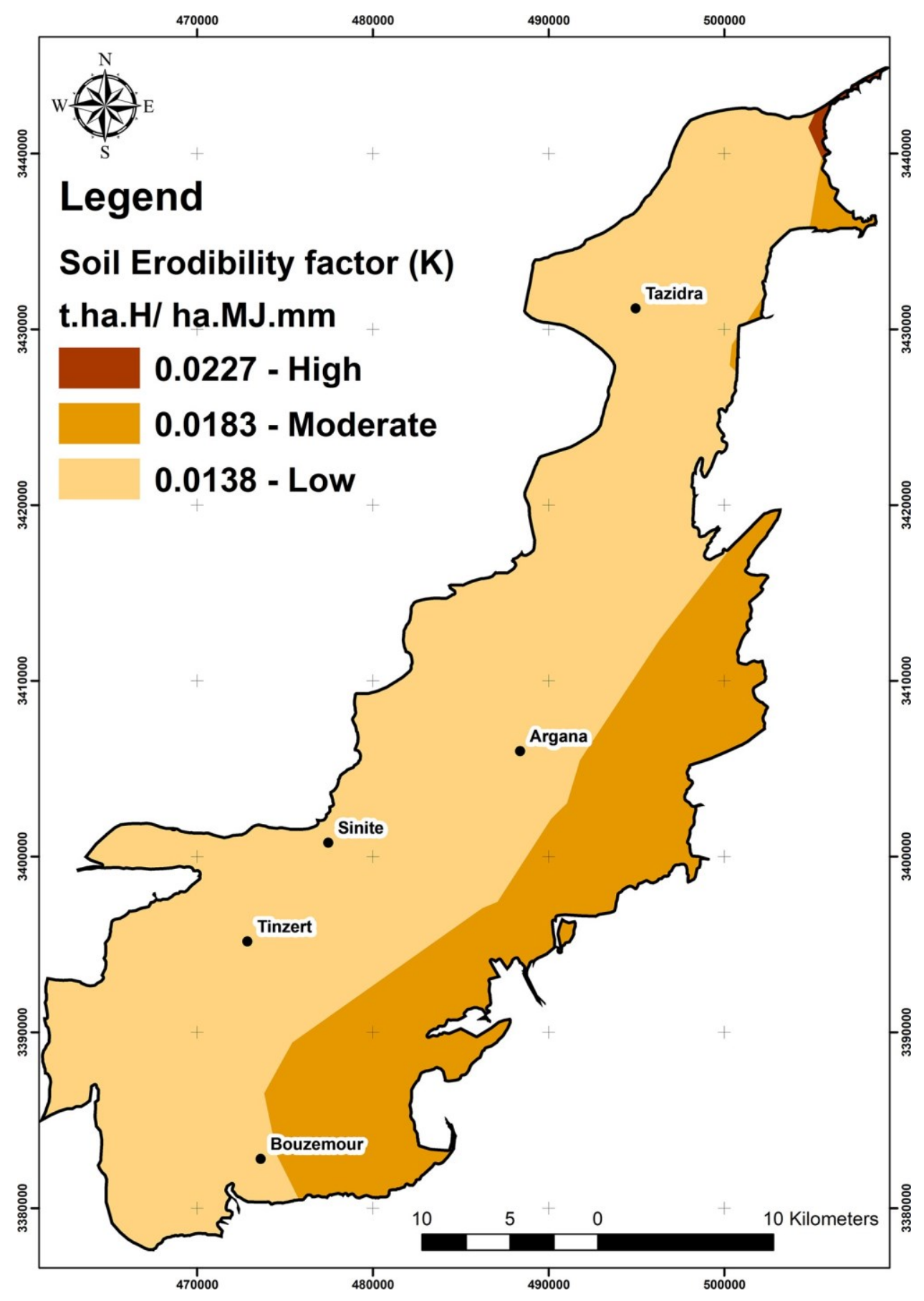

rates differ from one region to another, depending on the local influence of the various controlling factors.

The resulting soil loss map has been grouped using a classification adapted by FAO (1980). Numerous studies have shown the efficiency of soil loss maps (Edeso et al. 1997; Ramos Taipe 2001; Velásquez 2008; Ramírez 2010) for providing a significant qualitative distribution of soil loss and improved description of the intensity levels (low, moderate, average, high, very high and critical) of the erosion risk, based on particular interval values. map. It reveals an average annual soil loss of between 0 and $160.3 \mathrm{t} / \mathrm{ha} /$ year, and an average of $47.52 \mathrm{t} / \mathrm{ha} /$ year. This is equivalent to $5,233,840$ tons/year of deposits. The erosion 
Fig. 5 The spatial distribution of the topographic factor $(L S)$ in the Argana Corrider

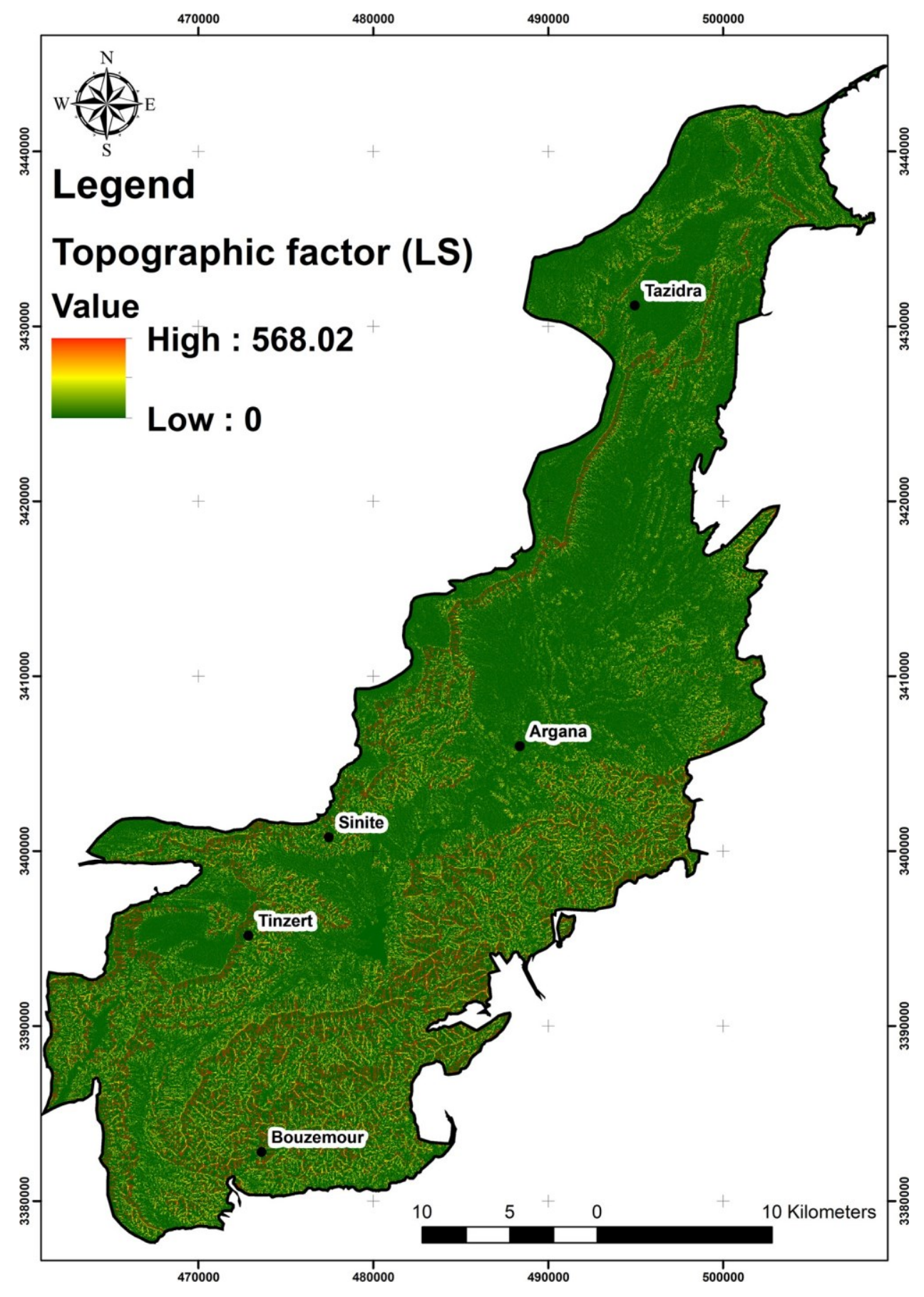

In the study area, using this classification allows us to obtain five main classes (Table 4), allowing spatial visualisation of the erosion and deposition areas. Erosion rates of between 0 and 5 t/ha/year occupy $96.15 \%$ of the area. These areas are distributed throughout the study area and corre- spond to shallow slopes. The areas of medium risk account for erosion rates that range from 5 to $50 \mathrm{t} / \mathrm{ha}$ /year. The latter areas occupy $3.07 \%$ of the total surface area. Areas where the rate of erosion is between 50 to 100 $\mathrm{t} / \mathrm{ha}$ /year represent only $0.39 \%$ of the total surface of the study area. Finally, areas with a very high risk of erosion with values of $>100$ $\mathrm{t} / \mathrm{ha} /$ year relate also to $0.39 \%$ of the area. These are mainly situated in areas with the steepest and most rugged terrains, most of which are located in the southern part of the Argana Corridor, with a considerable increase from the centre to the margins.

Interpretation of the soil loss map allows us to clearly identify areas exposed to erosion risk. Such areas are found throughout the land with moderate to steep slopes, distributed across almost the entire region, with a considerable 
Fig. 6 The spatial distribution of the vegetation cover factor

(C) in the Argana Corrider

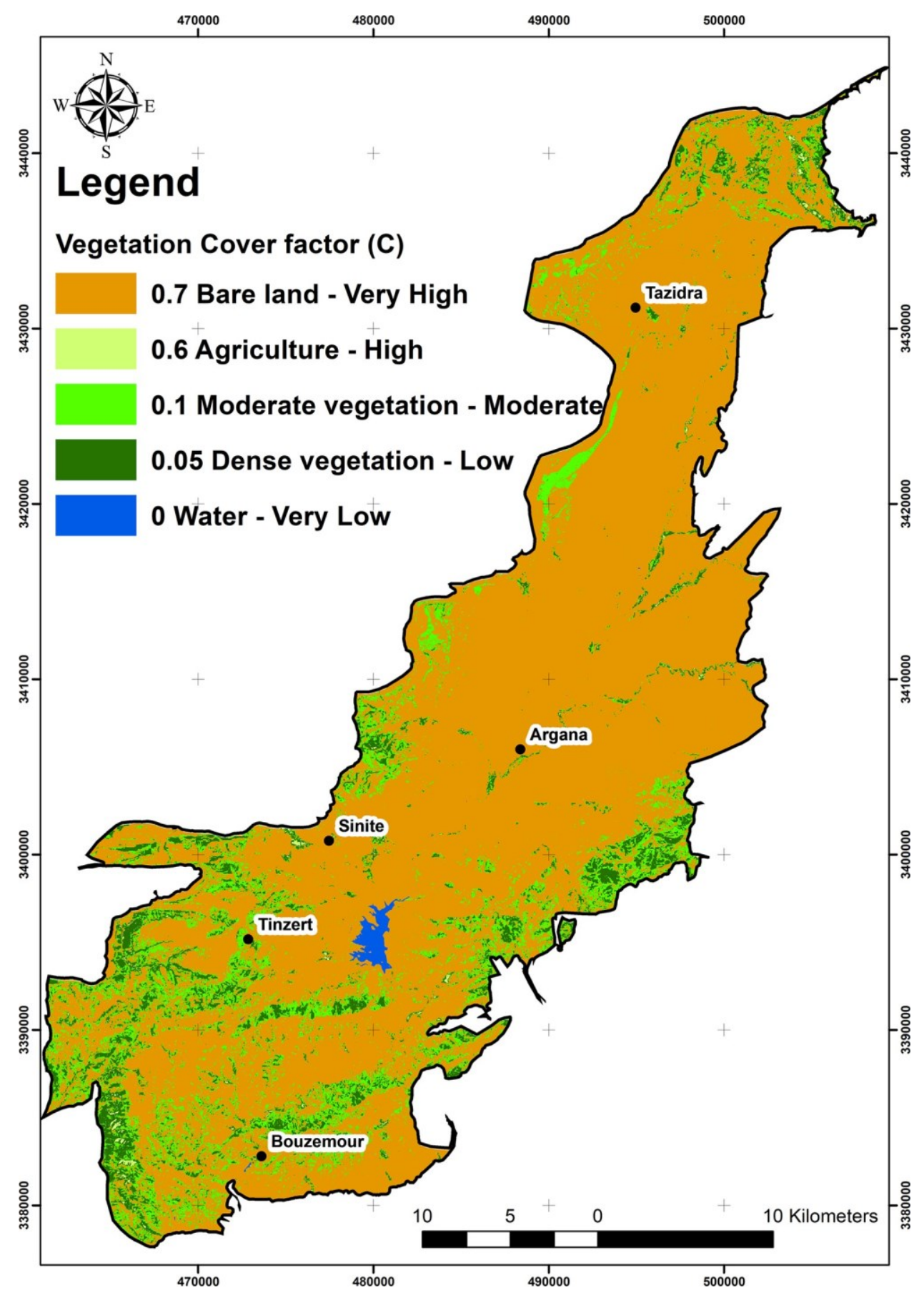

numerous studies conducted in similar semi-arid environments (Yjjou et al. 2014; Modeste et al. 2016; Elaloui et al. 2017; Bou-imajjane and Belfoul 2020) have shown that erosion is mainly triggered in these areas by rugged topography even with a significant recovery rate of vegetation cover. While topography is the main defining factor, its effect can be accentuated when combined with other factors, such as land cover management, soil conservation practices, rainfall aggressivity and soil erodibility. The in this area is topography, and soil loss is clearly focused in areas where the topography is important. In addition, 
Table 4 Classification of the vegetation cover factor $(C)$, soil conservation practices factor $(P)$ and soil loss (t/ha/year) by surface area in the Argana Corridor

\begin{tabular}{|c|c|c|c|c|c|c|c|c|c|}
\hline \multirow[t]{2}{*}{ Classes } & \multicolumn{3}{|c|}{ Vegetation cover factor (C) } & \multicolumn{3}{|c|}{ Soil conservation practices factor $(P)$} & \multicolumn{3}{|l|}{ Soil loss t/ha/year } \\
\hline & Value & Area (ha) & Area (\%) & Value & Area (ha) & Area (\%) & Value & Area (ha) & Area (\%) \\
\hline Very high & 0.70 & $87,747.82$ & 79.68 & 1.00 & $44,111.70$ & 40.05 & $>100$ (very high) & 429.29 & 0.39 \\
\hline High & 0.60 & 378.56 & 0.34 & 0.90 & $16,577.71$ & 15.05 & 50-100 (high) & 434.42 & 0.39 \\
\hline Moderate & 0.10 & $14,397.78$ & 13.07 & 0.80 & $16,035.20$ & 14.56 & 25-50 (average) & 479.59 & 0.44 \\
\hline Low & 0.05 & 7127.41 & 6.47 & 0.60 & $14,717.73$ & 13.36 & 5-25 (moderate) & 2896.11 & 2.63 \\
\hline Very low & 0.00 & 491.42 & 0.44 & 0.55 & $18,700.68$ & 16.98 & $0-5$ (low) & $105,903.60$ & 96.15 \\
\hline Total & & 110,143 & 100 & & 110,143 & 100 & & 110,143 & 100 \\
\hline
\end{tabular}

Fig. 7 The spatial distribution of the soil conservation practices factor $(P)$ in the Argana Corridor

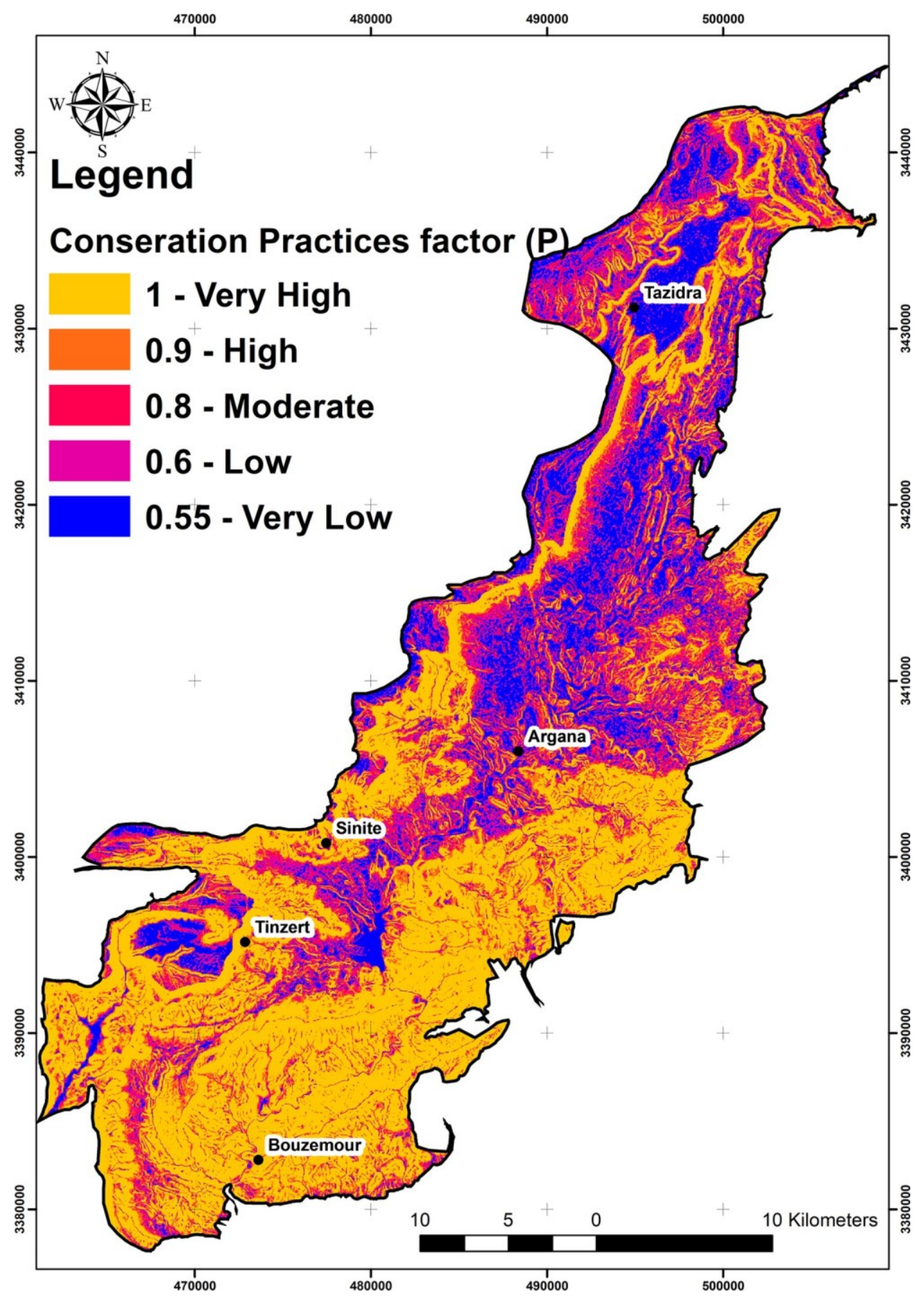


Fig. 8 The resulting potential erosion risk map in the Argana Corridor

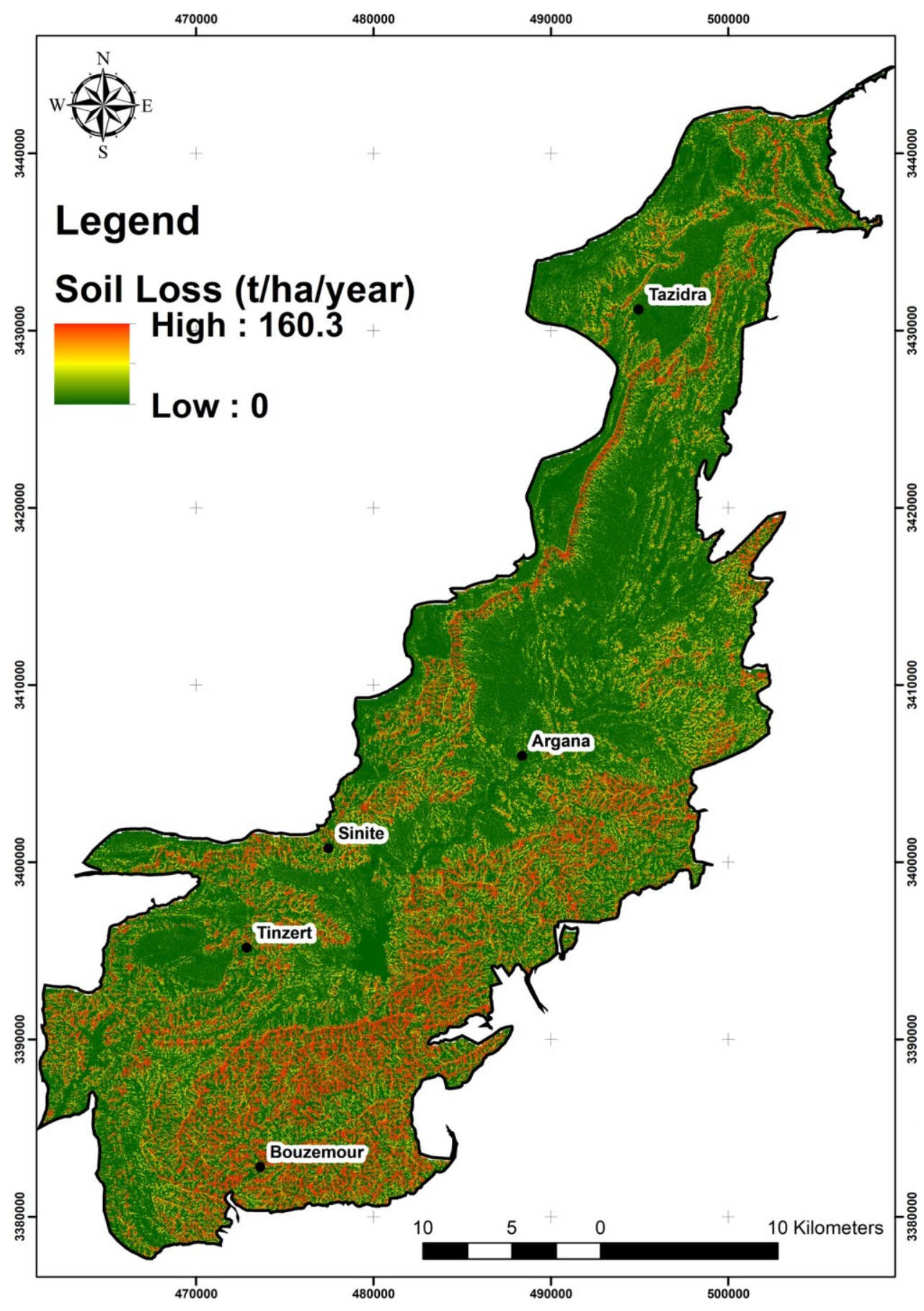

$4 \mathrm{M} \mathrm{t} /$ ha/year, where 1.374 Million t/ha/year of deposits is recorded in the Abdelmou- men dam (1981-1998), which forms part of our study area. The difference, between our results and the validation data, can be explained by the fact that the erosion estima- tion using the RUSLE predicts both induced and potential erosion. Furthermore, the data concerning the amount of deposits recorded represent only the amount of siltation in reported by Watershed Protection and Management project (WPM) of Morocco in 2003, showing that the High Atlas is combination and the interaction between all these
can drastically change the landscape of the region.

Field data in the area are very limited, and that is why the RUSLE approach is valuable and provides a good alternative to estimate soil erosion in data-scarce regions. However, we were able to compare our results with field measurements 
the dam and it does not take into consideration other soil losses in the area, contrary to our study that measures and quantifies the erosion amount across the entire area.

This model remains reliable in that, it allows managers and decision-makers to anticipate and plan interventions to combat or at least minimize the risk of erosion in areas of highest risk, without the need of an exhaustive list of field and long-term-based datasets, that are lacking in most water-sheds in Morocco and the Atlas Mountains.

\section{Conclusion}

Results reveal that the Argana Corridor and particularly the southern part is subject to a significant erosion risk, varying from 0 to $160.3 \mathrm{t} / \mathrm{ha}$ /year, with an average annual erosion rate of $47.52 \mathrm{t} / \mathrm{ha} / \mathrm{year}$, and an annual soil loss amount of $5,233,840$ tons. In the Argana Corridor, soil losses vary from the centre to the edge, where about $6 \%$ of the total surface area is subjected to moderate to very high risk of erosion. These areas are mainly located in moderate to very high slopes where the erosion is heightened by runoff.

Whilst all factors have been considered in the erosion process assessment, it is particularly the topographic factor that is enhanced when combined with other factors, itself a factor that has been heightened within the region in recent decades. The topography is considered to be the most important factor in this study, followed by the soil conservation practices, the vegetation cover factor, the erodibility factor and finally the climate aggressiveness. The interaction between these fac- tors collectively accelerates the erosion process.

The combination of the Universal Soil Loss Equation (RUSLE), GIS and remote sensing constitutes a reliable tool to compute soil loss map, using only available data of controlling factors of RUSLE model. The final result, which is a soil loss map, provides a detailed assessment of erosion risk representing the annual soil loss rate calculated for each pixel. The application of the RUSLE model, despite some limitations, has been a highly useful approach for delineating the areas at high risk of erosion which is even with the lack of data, and it constitutes a good alternative method for soil loss estimation.

The soil erosion risk is considered as irreversible and difficult to be stopped. Nevertheless, this risk can be minimized by adopting adequate conservation practices and land use management. Furthermore, managers can use the potential erosion map while planning for the conservation of priority areas as well as preserving those that could be potentially affected. All these outcomings make this study essential and useful for soil management in the region, enabling priority areas to be targeted.

\section{References}

Ambroggi R (1963) Etude géologique du Versant Meridional du Haut Atlas Occidental et de la plaine du Souss: Notes et Mémoires du Service Géologique du Maroc, v. 157. Bull Mus Comp Zool Harv Univ 133:153-225

Al-Arifi SN, Al-Agha RM, El-Nahhal ZY (2013) Hydrogeology and water quality of Umm Alradhma Aquifer, Eastern Saudi Arabia. J Environ Earth Sci 3(14):222-240

Arnoldus HMJ (1977) Methodology used to determine the maximum potential average annual soil loss due to sheet and rill erosion in Morocco. FAO Soils Bulletins (FAO)

Bahadur KK (2009) Mapping soil erosion susceptibility using remote sensing and GIS: a case of the Upper Nam Wa Watershed, Nan Province, Thailand. Environ Geol 57(3):695-705

Bizuwerk A, Taddese G, Getahun Y (2003) Application of GIS for modeling soil loss rate in Awash river basin, Ethiopia. International Livestock Research Institute (ILRI), Addis Ababa, Ethiopia, pp $1-11$

Boggs G, Devonport C, Evans K, Puig P (2001) GIS-based rapid assessment of erosion risk in a small catchment in the wet/dry tropics of Australia. Land Degrad Dev 12(5):417-434

Boiffin J (1994) Place des bassins versants expérimentaux dans les études sur l'érosion hydrique des sols. In : Du concept de BVRE à celui de zone atelier dans les recherches menées en eaux continentales. Actes du Séminaire national, hydrosystèmes. Paris: Cémagref, pp 197-201

Bonilla CA, Reyes JL, Magri A (2010) Water erosion prediction using the Revised Universal Soil Loss Equation (RUSLE) in a GIS framework, central Chile. Chil J Agric Res 70(1):159-169

Boudhar A, Duchemin B, Hanich L, Chaponnière A, Maisongrande $P$, Boulet G, Chehbouni A (2007) Analyse de la dynamique des surfaces enneigées du Haut Atlas marocain à partir des données SPOT-VEGETATION. Science et changements planétaires/ Sécheresse 18(4):278-288

Bou-imajiane L, Belfoul MA (2020) Soil Loss Assessment in Western High Atlas of Morocco: Beni Mohand Watershed Study Case. Appl Environ Soil Sci 2020

Brown RH (1980) Triassic rocks of Argana Valley, southern Morocco, and their regional structural implications. AAPG Bull 64(7):9881003

Dabral PP, Baithuri N, Pandey A (2008) Soil erosion assessment in a hilly catchment of North Eastern India using USLE, GIS and remote sensing. Water Resour Manag 22(12):1783-1798

López TDM, Aide TM, Scatena FN (1998) The effect of land use on soil erosion in the Guadiana watershed in Puerto Rico. Carib J Sci 34(3-4):298-307

Desmet PJJ, Govers G (1996) A GIS procedure for automatically calculating the USLE LS factor on topographically complex landscape units. J Soil Water Conserv 51(5):427-433

Edeso JM, Marauri P, Merino A, González MJ (1997) Determinación de la tasa de erosión hídrica en función del manejo forestal: la cuenca del río Santa Lucía (Gipuzkoa). Lurralde 20:67-104

Elaloui A, Marrakchi C, Fekri A, Maimouni S, Aradi M (2017) USLEbased assessment of soil erosion by water in the watershed upstream Tessaoute (Central High Atlas, Morocco). Model Earth Syst Environ 3(3):873-885

El-Nahhal Y, Tubail K, Safi M, Safi J (2013) Effect of treated waste water irrigation on plant growth and soil properties in Gaza Strip, Palestine. Amer J Plant Sci 04(09):1736-1743. https://doi. org/10.4236/ajps.2013.49213

FAO P (1980) UNESCO, 1980. Metodología provisional para la evaluación de la degradación de los suelos. Roma 
Foster GR, McCool DK, Renard KG, Moldenhauer WC (1981) Conversion of the universal soil loss equation to SI metric units. J Soil Water Conserv 36(6):355-359

Heinze S, Chen Y, El-Nahhal Y, Hadar Y, Jung R, Safi J, Marschner B (2014) Small scale stratification of microbial activity parameters in Mediterranean soils under freshwater and treated wastewater irrigation. Soil Biol Biochem 70:193-204

Heusch B (1971) Une méthode pour estimer l'écoulement et l'érosion dans un bassin. Application au Maghreb

Hoyos N (2005) Spatial modeling of soil erosion potential in a tropical watershed of the Colombian Andes. CATENA 63(1):85-108 Hudson N (1981) Soil conservation, 2nd edn. Comell University Press, Ithaca

Issa LK, Lech-Hab KBH, Raissouni A, El Arrim A (2016) Cartogra- phie quantitative du risque d'erosion des sols par approche SIG/ USLE au niveau du bassin versant Kalaya (Maroc Nord Occiden- tal). J Mater Environ Sci 7(8):2778-2795

Jalil NE (2001) Les vertébrés permiens et triasiques d’Afrique du Nord avec une description ne nouveaux Parareptiles Preiasaures (Amniota, Parareptila, Pareiasauria) du Premien du Maroc

Jasrotia AS, Singh R (2006) Modeling runoff and soil erosion in a catchment area, using the GIS, in the Himalayan region, India. Environ Geol 51(1):29-37

Jensen JR (2000) Remote sensing of the environment-an earth resource perspective. Prentice Hall Inc., Upper Saddle River

Kalman R (1967) Le facteur climatique de l'érosion dans le bassin du Sebou, Maroc. Projet Sebou

Lal R (1998) Soil erosion impact on agronomic productivity and environment quality. Crit Rev Plant Sci 17(4):319-464

Lu D, Li G, Valladares GS, Batistella M (2004) Mapping soil erosion risk in Rondonia, Brazilian Amazonia: using RUSLE, remote sensing and GIS. Land Degrad Dev 15(5):499-512

McCool DK, Brown LC, Foster GR, Mutchler CK, Meyer LD (1987) Revised slope steepness factor for the Universal Soil Loss Equation. Trans ASAE 30(5):1387-1396

Medina F, Vachard D, Colin J, Ouarhache D, Ahmamou M (2001) Charophytes et ostracodes du niveau carbonaté de Taourirt Imzilen (Membre d' Aglegal, Trias d' Argana); implications stratigraphiques. Bulletin de I'Institut Scientifique, Rabat, 23(January), 21-26

Merzouk A (1985) Relative erodibility of nine selected Moroccan soils as related to their physical, chemical and mineralogical properties. University of Minnesota

Merzouk A, Rayan J, Kacemi M (1993) A perspective on soil erosion in Morroco's dry land semi-arid zone. In: Actes du colloque International des Sciences du Sol: «Sciences du sol au développement, Rabat, Maroc

Modeste M, Abdellatif K, Nadia M, Zhang H (2016) Cartographie Des Risques De L'erosion Hydrique Par L'equation Universelle Revisee Des Pertes En Sols, La Teledetection Et Les Sig Dans Le Bassin Versant De L'ourika (Haut Atlas, Maroc). Eur Sci J 12(32):277. https://doi.org/10.19044/esj.2016.v12n32p277

Pandey A, Mathur A, Mishra SK, Mal BC (2009) Soil erosion mod- eling of a Himalayan watershed using RS and GIS. Environ Earth Sci 59(2):399-410

Ramírez L (2010) Estimación de la pérdida de suelos por erosión hídrica en la cuenca del río Juramento-Salta. Tesina de Grado. Universidad Nacional de Salta. Argentina

Ramos Taipe CL (2001) Modelamiento ambiental para analisis de susceptibilidad erosiva en la cuenca media y alta del rio Cañete y determinación del mapa de erosión. Lima, Peru: Universidad nacional agraria la Molina, p 26
Renard KG, Foster GR, Weesies GA, Porter JP (1991) RUSLE: revised universal soil loss equation. J Soil Water Conserv 46(1):30-33

Renard KG, Foster GR, Weesies GA, McCool DK, Yoder DC (1997) Predicting soil erosion by water: a guide to conservation planning with the Revised Universal Soil Loss Equation (RUSLE), vol 703. United States Department of Agriculture, Washington, DC

Roose E, Sarrailh JM (1990) Erodibilité de quelques sols tropicaux. Vingt années de mesure en parcelles d'érosion sous pluies naturelles. Cahiers d'ORSTOM SeHrie PeHdologie 25(1):2

Roose E, Kabore V, Guenat C (1993) Le zaï: fonctionnement, limites et amélioration d'une pratique traditionnelle africaine de réhabilitation de la végétation et de la productivité des terres dégradées en région soudano-sahélienne (Burkina Faso). Cahiers ORSTOM Série Pédologie 28(2):159-173

Roose E (1994) Introduction à la gestion conservatoire de l'eau, de la biomasse et de la fertilité des sols (GCES)

Safi J, El-Nahhal Y, Safi M (2018) Particle size distribution and hydrau- lic conductivity in coastal non-agricultural land in Gaza Coastal Plain Int J Geosci 9:10. https://doi.org/10.4236/ijg.2018.910037 Sanoussi

Manzo LM (2011) Utilisation de la géomatique pour la contri- bution à la cartographie des sols de la région de Tétouan. Mémoire IAV Hassan II

Sharpley AN, Williams JR (1990) EPIC. Erosion/productivity impact calculator: 1. Model documentation. 2. User manual

Shin GJ (1999) The analysis of soil erosion analysis in watershed using GIS (Doctoral dissertation, Ph.D. Dissertation, Department of Civil Engineering, Gang-won National University)

Tixeront M (1973) Lithostratigraphie et minéralisations cuprifères syngénétiques et familières des formations détritiques permotria- siques du couloir d'Argana (Haut-Atlas occidental, Maroc). Notes \& Mém Serv Géol Maroc 33:147-177

Tixeront M (1974) Carte geologique et mineralisations du couloir d'Argana. Maroc, Serv. Geol. Notes Mem. Serv

Van der Knijff JM, Jones RJA, Montanarella L (2000) Soil erosion risk assessment in Europe, EUR 19044 EN. Office for official publications of the European communities, Luxembourg, p 34

Velásquez S (2008) Erosión de suelos utilizando la EUPSR (RUSLE). Coronado, Costa Rica: Centro agronómico tropical de investigación y enseñanza

Vezena K, Bonn F (2006) Modélisation et analyse de la dynamique spatio-temporelle des relations société-érosion et pollution diffuse en milieu agricole-étude de cas en Vietnam et au Québec. Interaction Nature-Société, analyse et modèles. UMR6554 LETG

Wang G, Gertner G, Fang S, Anderson AB (2003) Mapping multiple variables for predicting soil loss by geostatistical methods with TM images and a slope map. Photogramm Eng Remote Sens 69(8):889-898

Wilson JP, Lorang MS (2000) Spatial models of soil erosion and GIS Spatial models and GIS: new potential and new models. In: Fotheringham AS, Wegener M (eds) Taylor \& Francis, Philadelphia, pp 83-108

Wischmeier WH, Smith DD (1978) Predicting rainfall erosion losses-a guide to conservation planning

Yjjou M, Bouabid R, El Hmaidi A, Essahlaoui A, El Abassi M (2014) Modélisation de l'érosion hydrique via les SIG et l'équation universelle des pertes en sol au niveau du bassin versant de l'Oum Er-Rbia. Int J Eng Sci 3(8):83-91 